\title{
THE RESULTS OF THE RESEARCH ON PHYSICAL AND MECHANICAL PROPERTIES OF ROCK ANALOGUES AND MOON SOILS
}

\section{Introduction}

The authors of the article, employees of The Department of Geomechanics, Civil Engineering and Geotechnics, took part in research carried out within an international project entitled Instrument "CHOMIK" ("HAMSTER") of Phobos Sample Return Mission, supervised by the Space Investigation Center at the Polish Academy of Science. The research carried out looked at the basic properties of materials found on the surface, or close-to-surface sphere of planets' and moons in the Solar System.

Due to the conditions where they came into being, the materials on the surface or just under the surface of the local area can maintain continuity, which means they can be a certain variety of solid rocks. Rocks forming in conditions of considerably lower gravity than that of earth have a volumetric density which can be repeatedly lower than that of the more familiar solid rocks that occur in our conditions e.g., sandstones, limestones, granites or shales.

As a consequence of the long-lasting effect of local erosion factors which occur on remote moons, solid materials can undergo destruction, cracking and crushing, changing themselves into a disintegrated medium (like soils on the surface of the earth).

The tests were carried out on sample materials delivered by the Space Investigation Center of the Polish Academy of Science. The tests focused on determination density and volumetric/bulk density of solid rocks and loose materials (granular) and porosity. Tests on mechanical properties, which would enable the determining of the way these rocks behave under the influence of outer loads, were considered to be the most important factor. These quantities include: uniaxial compressive strength, internal friction angle and cohesion as the shear strength parameters, and coefficient of consolidation. In total, the properties of 18 different materials were tested.

\footnotetext{
* AGH University of Science and Technology, Krakow; mkolano@agh.edu.pl; mazurek@agh.edu.pl
} 
The tests were done in the Research Laboratory on Rocks and Stoneware Properties at the Department of Mining and Geoengineering AGH accredited by Polish Accreditation Center - accreditation certificate AB 298.

\section{Characteristic of the material for testing}

The tested materials are analogues of rocks and lunar soils, part of which are loose materials and the other part are solid materials, highly or medium porous.

The samples of loose material, among others, are:

- Quartz sand (Fig. 1a),

- Phobos analogue - various-grained sand (Fig. 1b),

- JSC 1A - analogue to the lunar mare regions (lunar regolith simulant), joint of sandy fraction with silt fraction (JSC-1A-1 - silt sand, JSC-1A-2 silt sand) (Fig. 1c, d),

- Chenobi - lunar highlands regolith physical simulant, joint of silt fractions and sand fractions with bigger grains (1-7 mm) (Fig. 2a),

- AGK 2010 - lunar regolith simulant, joint of silt fraction and sand fraction (Fig. 2b),

- Gabbro and olivine - silt fraction and fine sand fraction (Fig. 2c),

- Gabbro - silt, sand and gravel fractions (Fig. 2d).

a)

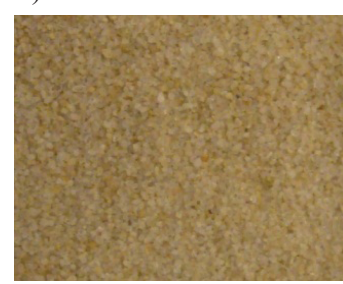

b)

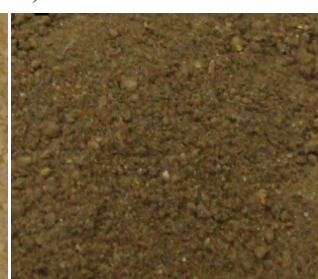

c)

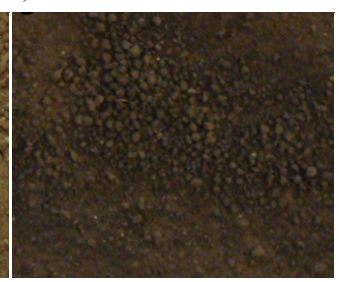

d)

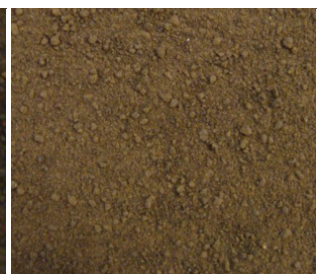

Fig. 1. Samples of loose material: a) Quartz sand; b) Phobos analogue; c) JSC-1A-1; d) JSC-1A-2

a)

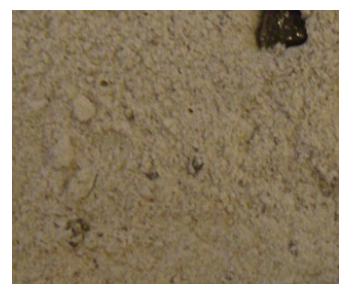

b)

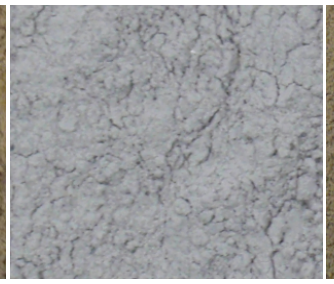

c)

d)

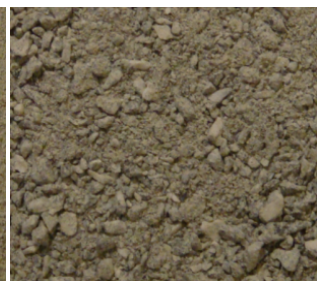

Fig. 2. Samples of loose material: a) Chenobi; b) AGK 2010; c) Gabbro and olivine; d) Gabbro (4)

The samples of solid material, among others, are:

- Foam - highly porous material, the appearance similar to foaming glass (F1 - grey, F2 - black, F3 - white) (Fig. 3a, b, c),

- Ytong - cellular concrete (Fig. 3d). 
a)

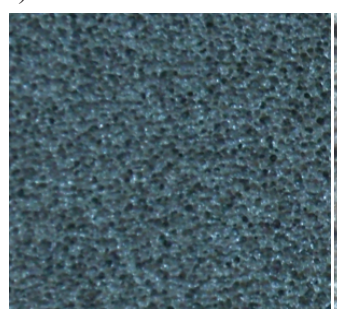

b)

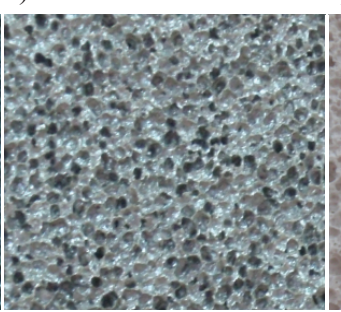

c)

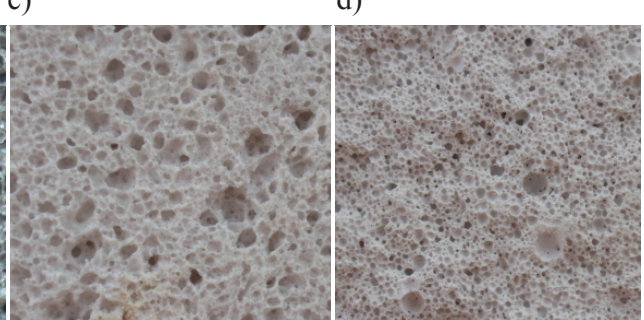

Fig. 3. Samples of solid material: a) Foam F1; b) Foam F2; c) Foam F3; d), Ytong

The tests were carried out to determin: density, bulk density (loose material), volumetric density (solid material), coefficient of consolidation, shear strength and compressive strength.

\section{Determination of density, volumetric density and porosity}

Bulk density of all loose material samples was determined in accordance with the recommendation of norm PN-EN 1097-3 [1], from mass ratio to the volume of the tested material in its loose state. Volumetric density of the tested solid material was determined with the direct method after the determination of mass and dimensions of regular samples used for strength tests. The use of the method presented in norm PE-EN 1936 [2] was impossible due to the hydrophobic properties of the material, and susceptibility to soaking of Ytong samples. Density was determined using the psychometric method in accordance with norm PN-EN 1936 [2]. In all cases two determinations for each were done.

The total porosity of the solid material was calculated for density and volumetric density, while for loose materials using dry density of the soil skeleton and density $[2,3]$.

The results of tests and calculations are juxtaposed in Table 1.

TABLE 1

Density and porosity of tested materials

\begin{tabular}{|c|c|c|c|c|c|}
\hline No. & Sample ID & $\begin{array}{c}\text { Bulk density, } \\
{\left[\mathbf{k g} / \mathbf{m}^{3}\right]}\end{array}$ & $\begin{array}{c}\text { Volumetric } \\
\mathbf{d e n s i t y , ~} \\
{\left[\mathbf{k g} / \mathbf{m}^{3}\right]}\end{array}$ & $\begin{array}{c}\text { Density, } \\
{\left[\mathbf{k g} / \mathbf{m}^{3}\right]}\end{array}$ & $\begin{array}{c}\text { Average } \\
\text { porosity, } \\
{[\mathbf{\%}]}\end{array}$ \\
\hline 1 & Quartz sand & 1508 & - & 2660 & 43.30 \\
\hline 2 & Phobos analogue & 995 & - & 2244 & 55.66 \\
\hline 3 & JSC - 1A-1 & 1584 & - & 2827 & 43.96 \\
\hline 4 & JSC - 1A-2 & 1529 & - & 2798 & 45.36 \\
\hline 5 & Chenobi & 1481 & - & 2673 & 44.59 \\
\hline 6 & AGK 2010 & 1414 & - & 2592 & 45.44 \\
\hline
\end{tabular}


TABLE 1 cont.

\begin{tabular}{|c|c|c|c|c|c|}
\hline No. & Sample ID & $\begin{array}{c}\text { Bulk density, } \\
{\left[\mathbf{k g} / \mathbf{m}^{\mathbf{3}}\right]}\end{array}$ & $\begin{array}{c}\text { Volumetric } \\
\mathbf{d e n s i t y ,} \\
{\left[\mathbf{k g} / \mathbf{m}^{3}\right]}\end{array}$ & $\begin{array}{c}\text { Density, } \\
{\left[\mathbf{k g} / \mathbf{m}^{3}\right]}\end{array}$ & $\begin{array}{c}\text { Average } \\
\text { porosity, } \\
{[\%]}\end{array}$ \\
\hline 7 & Gabbro and olivine & 1589 & - & 2891 & 45.05 \\
\hline 8 & Gabbro & 1682 & - & 2982 & 43.60 \\
\hline 9 & Foam F1 & - & 172 & 2633 & 93.54 \\
\hline 10 & Foam F2 & - & 122 & 2674 & 95.51 \\
\hline 11 & Foam F3 & - & 257 & 2369 & 89.03 \\
\hline 12 & Ytong & - & 586 & 2526 & 76.64 \\
\hline
\end{tabular}

It follows from the juxtaposition in Table 1 that the bulk density of prepared loose (granular) materials and their porosity in a loose state were similar to sand or fine aggregates from earth's rocks (with the exception of material Phobos analogue). Whereas volumetric density of prepared solid rocks was several, dozen or more times lower than the one of typical rocks on earth, and their porosity exceeded $90 \%$.

\section{Coefficient of consolidation}

The ccoefficient of consolidation was determined using Taylor's method on the grounds of the results of compressibility testing. The method is based on plotting a graph of changes of the sample height depending on time square root [4].

Coefficient of consolidation was calculated by formula:

$$
c=0.848 \frac{h^{2}}{t}
$$

where:

$h$ - half of sample height in oedometer [cm],

$t_{90}-$ time when consolidation occurs in $90 \%[\mathrm{~s}]$.

Research on the consolidation coefficient was carried out in an oedometer without water inflow, with gradual load change $(12.5,25,50,100,200,400 \mathrm{kPa})$. Loose materials were tested: Quartz sand, Phobos analogue, JSC 1A-1, JSC 1A-2, Chenobi, AKG2010, Gabbro and olivine, Gabbro and solid materials: Foam F1, F2 and F3. The results of coefficient of consolidation testing are presented in Table 2.

It follows from the juxtaposition in Table 2 that in most tested loose materials, the value coefficient of consolidation reached a maximum during the first steps of loading, and during the next steps lowered. Solid materials did not show such regularity of behavior. The results presented show significant fluctuations of the coefficient of consolidation - the irregular increases and declines. 
TABLE 2

Coefficient of consolidation, $\left[\mathrm{cm}^{2} / \mathrm{s}\right]$

\begin{tabular}{|c|c|c|c|c|c|c|c|c|}
\hline \multirow{2}{*}{ No. } & \multirow{2}{*}{ Sample ID } & \multirow{2}{*}{$\begin{array}{l}\text { Kind of } \\
\text { material }\end{array}$} & \multicolumn{6}{|c|}{ Perpendicular stresses, $[\mathrm{kPa}]$} \\
\hline & & & 12.5 & 25 & 50 & 100 & 200 & 400 \\
\hline 1 & Foam F1 & \multirow{3}{*}{ Sold } & 0.0177 & 0.0148 & 0.0051 & 0.0138 & 0.0116 & 0.0125 \\
\hline 2 & Foam F2 & & 0.0054 & 0.0062 & 0.0112 & 0.0034 & 0.0085 & 0.0058 \\
\hline 3 & Foam F3 & & 0.0098 & 0.0171 & 0.0178 & 0.0208 & 0.0138 & 0.0132 \\
\hline 4 & Quartz sand & \multirow{7}{*}{ Loose } & 0.0215 & 0.0232 & 0.0218 & 0.0204 & 0.0210 & 0.0198 \\
\hline 5 & Phobos analogue & & 0.0208 & 0.0236 & 0.0198 & 0.0185 & 0.0178 & 0.0175 \\
\hline 6 & JSC $1 \mathrm{~A}-1$ & & 0.0226 & 0.0212 & 0.0222 & 0.0152 & 0.0146 & 0.0068 \\
\hline 7 & JSC $1 \mathrm{~A}-2$ & & 0.0219 & 0.0220 & 0.0244 & 0.0156 & 0.0130 & 0.0246 \\
\hline 8 & Chenobi & & 0.0216 & 0.0197 & 0.0200 & 0.0203 & 0.0186 & 0.0182 \\
\hline 9 & Gabbro and olivine & & 0.0122 & 0.0065 & 0.0192 & 0.0108 & 0.0098 & 0.0104 \\
\hline 10 & Gabbro & & 0.0215 & 0.0216 & 0.0197 & 0.0138 & 0.0164 & 0.0169 \\
\hline
\end{tabular}

\section{Shear and compressive strength}

\subsection{Strength in shearbox apparatus}

All loose (granular) materials in dry state were tested for shear strength. They were tested in shearbox apparatus, at normal stresses 100,200, 300 and $400 \mathrm{kPa}$, in accordance with norm PN-B-04481:1988 [3]. As the value of shear strength, maximum shear stresses were accepted within the scope of strains $\varepsilon \leq 10 \%$.

On the grounds of the strength testing, parameters of Coulomb's hypothesis were determined: cohesion and internal friction angle. The results of the tests under discussion are juxtaposed in Figure 4 and Table 3, and their graphical interpretation is presented in Figure 4. Because some results were atypical, samples of each material were tested twice. Mean values of cohesion and internal friction angle were obtained from the statistical study of all results of each individual sample.

Low cohesion values $(1.27-4.44 \mathrm{kPa})$ and high values of internal friction angle $\left(32.60-45.13^{\circ}\right)$ (with the exception of high results obtained for sample Phobos analogue), are the features of cohesionless soils. Such values are characteristic for fine sands, silt sands and humus sands. In contrast, the values obtained for friction angle for sample Gabbro $\left(45.13^{\circ}\right)$ in earth's conditions is characteristic for gravel formations.

Atypical, high cohesion was shown by granular material Phobos analogue. It is worth mentioning that they were tested in air-dry state. 
a)

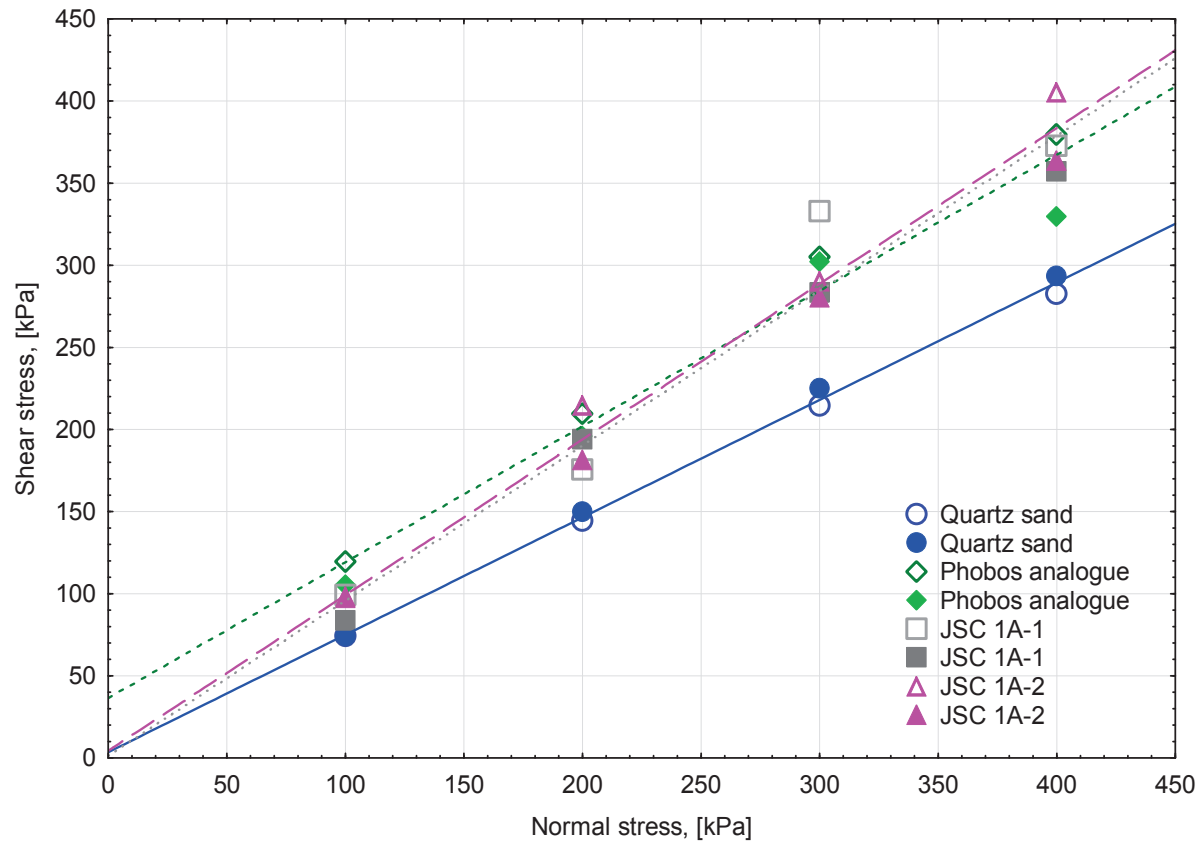

b)

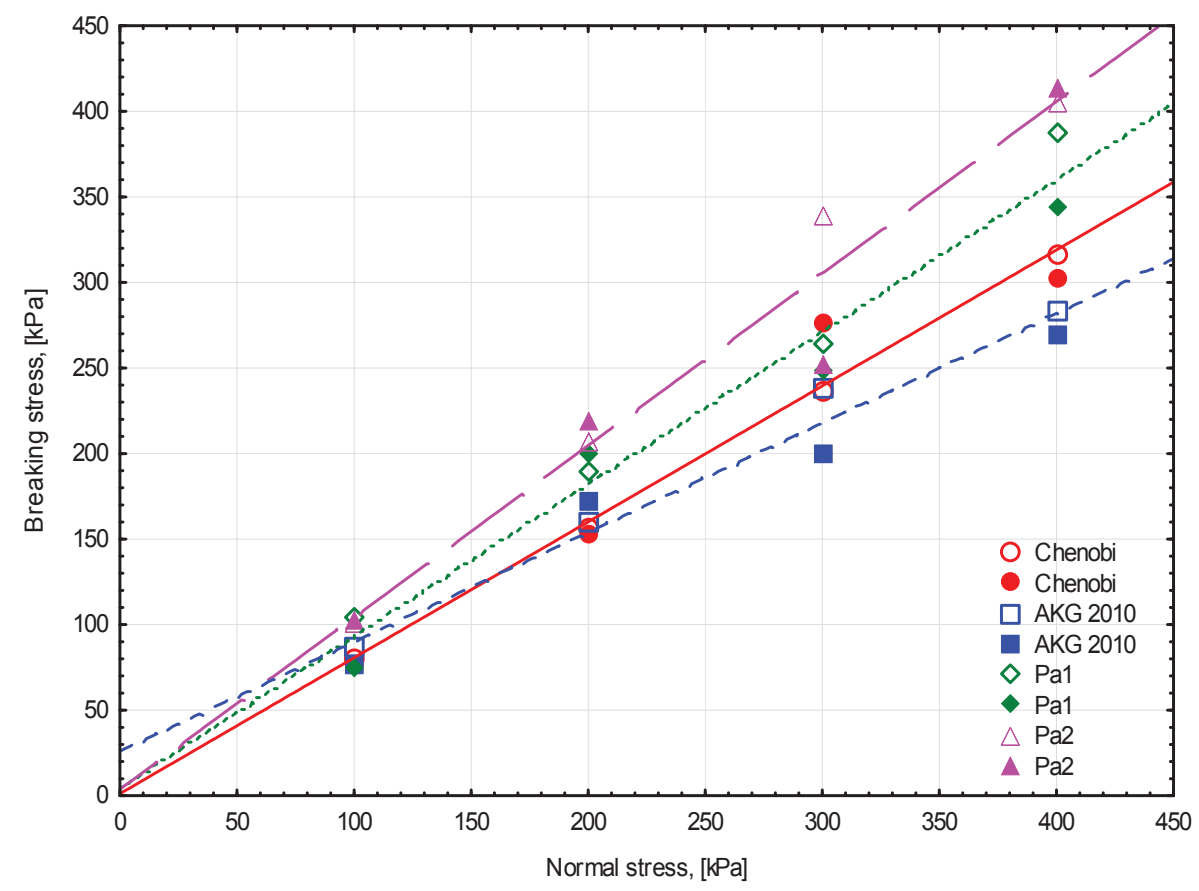

Fig. 4. Graphs of rectilinear dependence $\tau_{\mathrm{f}}=\mathrm{f}\left(\sigma_{\mathrm{n}}\right)$ : a) samples ID: Quartz sand, Phobos analogue, JSC 1A-1, JSC 1A-2; b) samples ID: Chenobi, AGK 2010, Gabbro and olivine, Gabbro 
TABLE 3

Strength parameters of all tested loose materials

\begin{tabular}{|c|c|c|c|c|c|}
\hline No. & Sample ID & $\begin{array}{c}\text { Cohesion } c, \\
{[\mathrm{kPa}]}\end{array}$ & $\begin{array}{c}\text { Internal friction } \\
\text { angle } \varphi, \\
{\left[^{\circ}\right]}\end{array}$ & $\begin{array}{c}\text { Average } \\
\text { coherence } c, \\
{[\mathbf{k P a}]}\end{array}$ & $\begin{array}{c}\text { Average internal } \\
\text { friction angle } \varphi \text {, } \\
{\left[^{\circ}\right]}\end{array}$ \\
\hline 1 & \multirow{2}{*}{ Quartz sand } & 4.75 & 34.86 & \multirow{2}{*}{3.47} & \multirow{2}{*}{35.57} \\
\hline 2 & & 2.18 & 36.26 & & \\
\hline 3 & \multirow{2}{*}{$\begin{array}{l}\text { Phobos } \\
\text { analogue }\end{array}$} & 34.49 & 41.20 & \multirow{2}{*}{36.40} & \multirow{2}{*}{39.61} \\
\hline 4 & & 38.31 & 37.94 & & \\
\hline 5 & \multirow{2}{*}{ JSC 1A-1 } & 0.63 & 44.37 & \multirow{2}{*}{1.27} & \multirow{2}{*}{43.36} \\
\hline 6 & & 1.92 & 43.31 & & \\
\hline 7 & \multirow{2}{*}{ JSC 1A-2 } & 2.54 & 44.94 & \multirow{2}{*}{4.30} & \multirow{2}{*}{43.47} \\
\hline 8 & & 6.06 & 41.93 & & \\
\hline 9 & \multirow{2}{*}{ Chenobi } & 0.16 & 38.27 & \multirow{2}{*}{1.18} & \multirow{2}{*}{38.46} \\
\hline 10 & & 2.19 & 38.66 & & \\
\hline 11 & \multirow{2}{*}{ AGK2010 } & 3.70 & 38.10 & \multirow{2}{*}{2.34} & \multirow{2}{*}{36.94} \\
\hline 12 & & 0.98 & 35.75 & & \\
\hline 13 & \multirow{2}{*}{$\begin{array}{l}\text { Gabbro and } \\
\text { olivine }\end{array}$} & 5.12 & 42.76 & \multirow{2}{*}{4.44} & \multirow{2}{*}{41.66} \\
\hline 14 & & 3.75 & 40.52 & & \\
\hline 15 & \multirow{2}{*}{ Gabbro } & 2.89 & 46.11 & \multirow{2}{*}{3.77} & \multirow{2}{*}{45.13} \\
\hline 16 & & 4.64 & 44.13 & & \\
\hline
\end{tabular}

\subsection{Strength in triaxial compression apparatus}

Testing of shear strength in triaxial stresses' state was carried out on solid material samples. The samples F1, F2 and F3 were tested by means of UU (unconsolidated undrained) method, which means without initial consolidation and water outlet during shearing.

Triaxial shearing of the Ytong material was done in a pressure chamber, which maintains the pressure applied, making use of a hydraulic press. During the tests, the values of axial strain were recorded regarding the function of applied axial loads, with a constant value of radial stresses (Fig. 2). The aim of the strength tests in the apparatus (chamber) of triaxial shearing was also carried out to determine the cohesion and internal friction angle. These quantities were calculated by means of the stress path method [5]. The obtained results are juxtaposed in Tables 4 and 5, and illustrated in Figure 2.

During testing, samples F1, F2 and F3 did not undergo any dynamic brittle failure or significant strains (with the exception of sample F3/1 - brittle failure) under maximum load values. Whereas the samples of cellular concrete (1 and 2) at lower pressure values in the chamber, underwent brittle failure, and sample 3 tested at pressure approximately three times higher underwent significant volumetric strains with partial maintaining cohesive. 
TABLE 4

Strength parameters of tested solid materials

\begin{tabular}{|c|c|c|c|c|c|c|}
\hline No. & Sample ID & $\begin{array}{c}\text { Volumetric } \\
\text { density } \rho, \\
{\left[\mathrm{kg} / \mathrm{m}^{3}\right]}\end{array}$ & $\begin{array}{c}\text { Principal } \\
\text { stress } \sigma_{3}, \\
{[\mathrm{kPa}]}\end{array}$ & $\begin{array}{c}\text { Principal } \\
\text { stress } \sigma_{1}, \\
{[\mathrm{kPa}]}\end{array}$ & $\begin{array}{c}\text { Cohesion } c, \\
\quad[\mathrm{kPa}]\end{array}$ & $\begin{array}{c}\text { Internal friction } \\
\text { angle } \varphi, \\
{\left[^{\circ}\right]}\end{array}$ \\
\hline 1 & Foam F1/3 & 171 & 100 & 1191 & \multirow{2}{*}{378.40} & \multirow{2}{*}{17.94} \\
\hline 2 & Foam F1/4 & 171 & 200 & 1404 & & \\
\hline 3 & Foam F2/1 & 119 & 200 & 714 & \multirow{3}{*}{122.08} & \multirow{3}{*}{16.45} \\
\hline 4 & Foam F2/2 & 125 & 300 & 872 & & \\
\hline 5 & Foam F2/3 & 118 & 100 & 505 & & \\
\hline 6 & Foam F3/1 & 259 & 100 & 1746 & \multirow{2}{*}{988.40} & \multirow{2}{*}{16.40} \\
\hline 7 & Foam F3/2 & 263 & 200 & 2920 & & \\
\hline 8 & Ytong 1 & 582 & 2000 & 4299 & \multirow{3}{*}{805} & \multirow{3}{*}{5.23} \\
\hline 9 & Ytong 2 & 586 & 7000 & 10183 & & \\
\hline 10 & Ytong 3 & 585 & 2500 & 4622 & & \\
\hline
\end{tabular}

TABLE 5

Appearance of samples after testing

\begin{tabular}{|c|c|c|c|c|}
\hline $\begin{array}{l}\text { Radial } \\
\text { stress, } \\
{[\mathrm{kPa}]}\end{array}$ & $\begin{array}{l}\text { Sample } \\
\text { number }\end{array}$ & $\begin{array}{c}\text { Appearance of } \\
\text { a sample before } \\
\text { testing }\end{array}$ & $\begin{array}{c}\text { Appearance of } \\
\text { a sample after } \\
\text { testing }\end{array}$ & Way of failure \\
\hline \multicolumn{5}{|c|}{ Foam F1 } \\
\hline 100 & 3 & & & $\begin{array}{l}\text { Laminar crushing of a sample } \\
\text { at the base side where } \\
\text { perpendicular force was applied. } \\
\text { Tests were finished when } 10 \% \text { of } \\
\text { axial strains were obtained }\end{array}$ \\
\hline 200 & 4 & & & $\begin{array}{l}\text { Laminar crushing of a sample } \\
\text { at the base side where } \\
\text { perpendicular force was applied. } \\
\text { Tests were finished when } 15 \% \text { of } \\
\quad \text { axial strains were obtained }\end{array}$ \\
\hline & & & & \\
\hline
\end{tabular}


TABLE 5 cont.

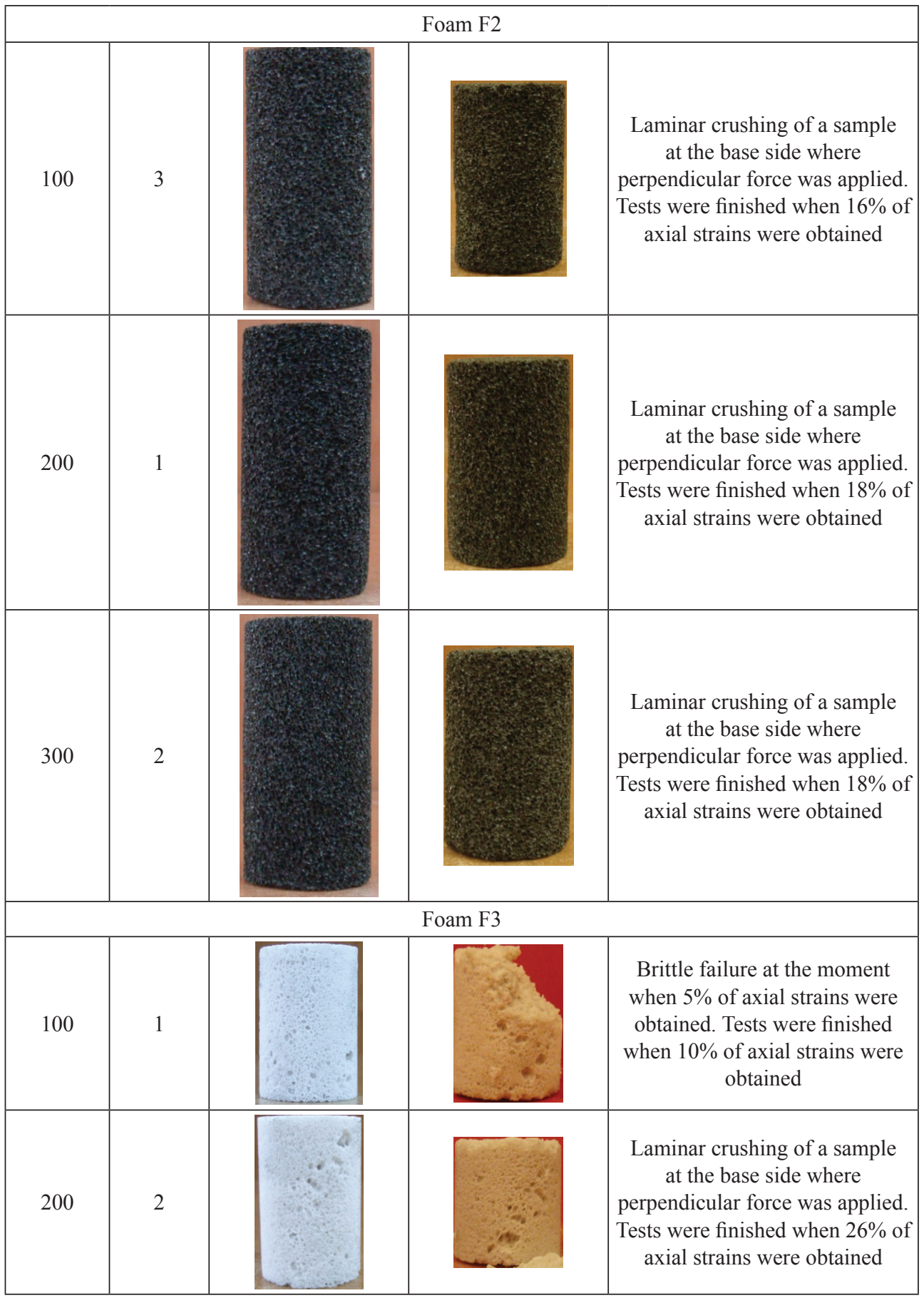


TABLE 5 cont.

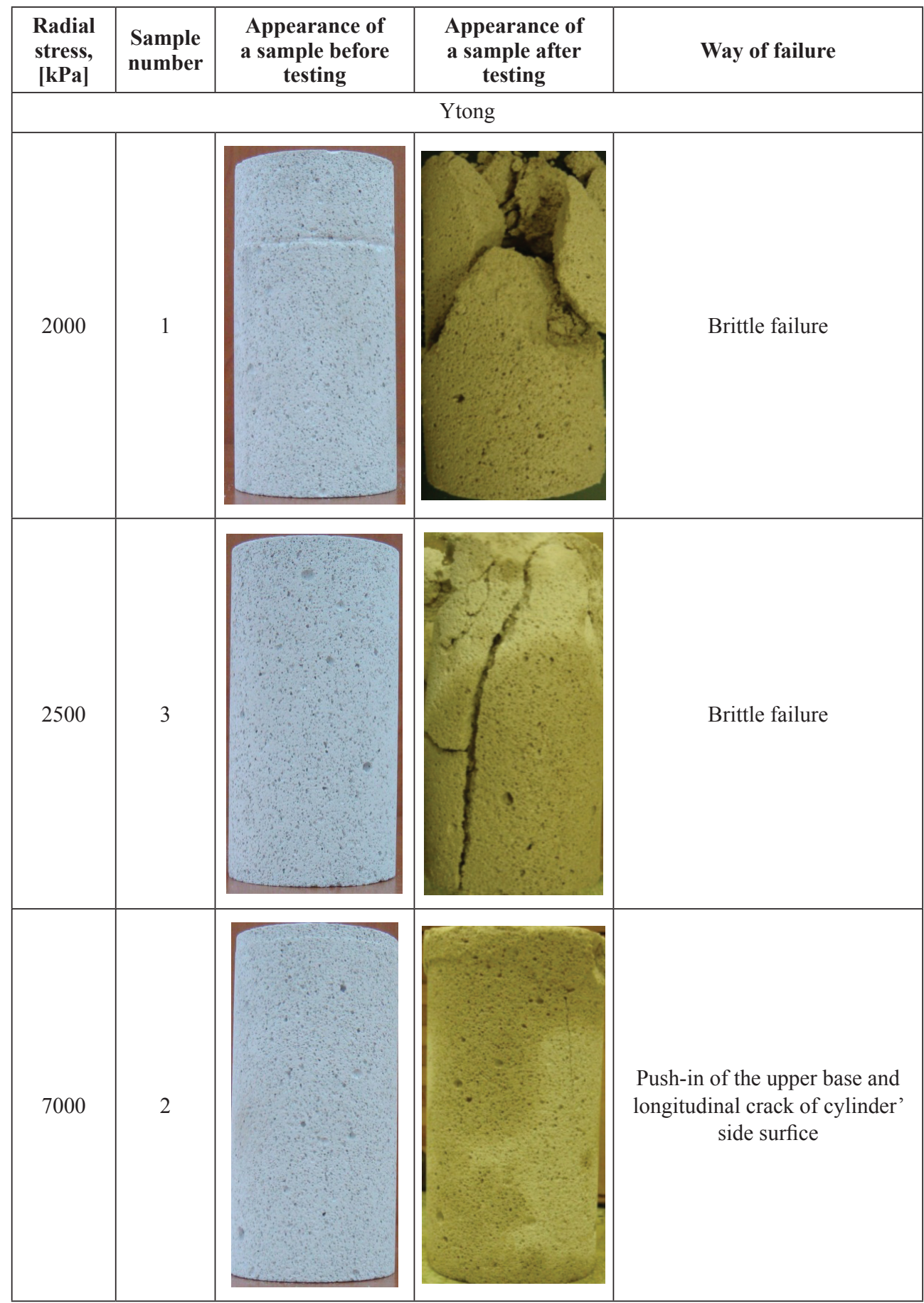




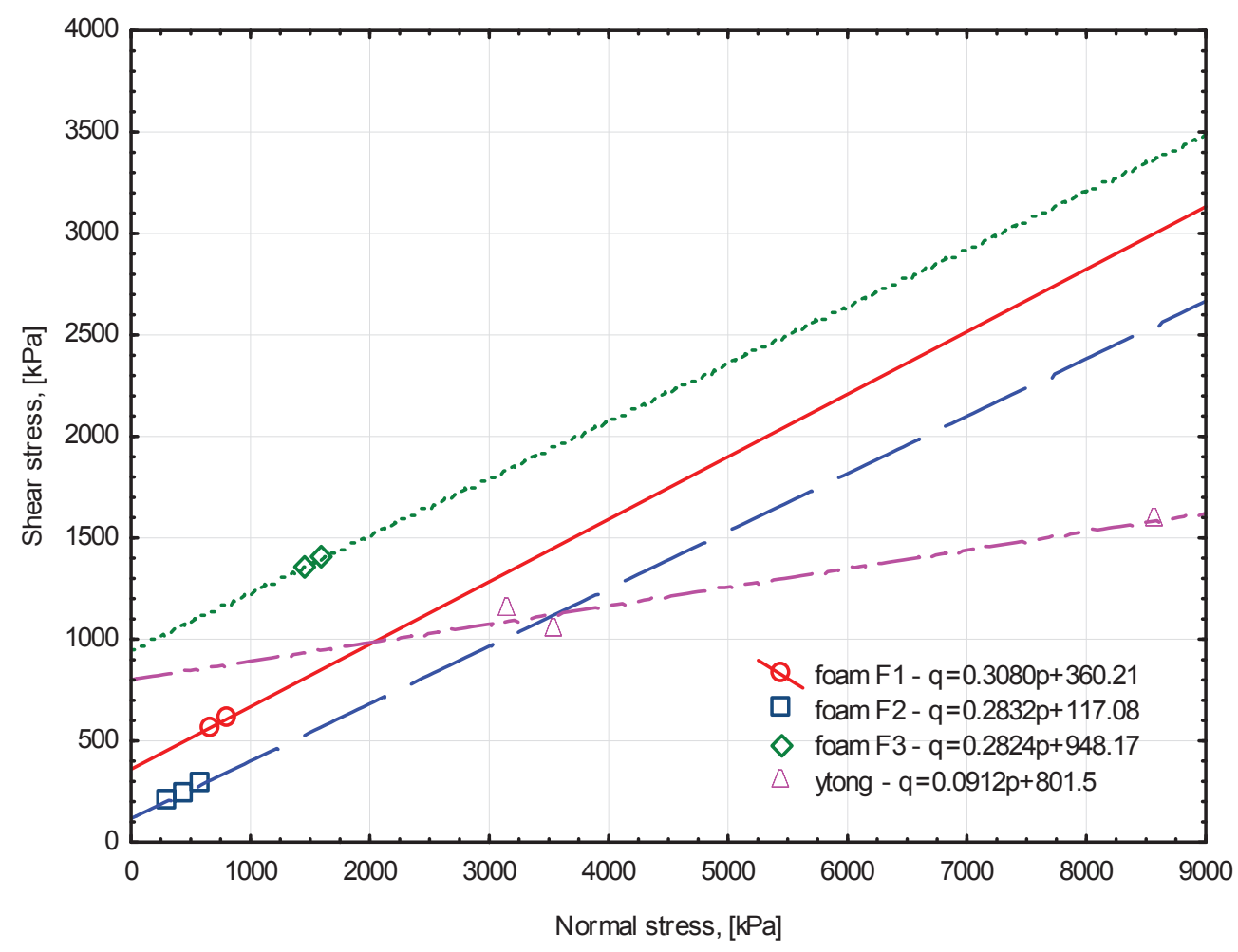

Fig. 5. Paths of stresses $q=f(p)$ of tested materials

\subsection{Compressive strength}

Compressive strength in uniaxial state was determined as maximum force ratio to crosssectional area.

The tests were carried out with a multiplex CBR press (samples F1, F2 and F3) and hydraulic press (samples: Ytong 4, Ytong 5, Ytong 6). The tested samples of Foam material were cylinder-shaped of $38 \times 76 \mathrm{~mm}$ dimensions, whereas Y tong material was cube-shaped of $60 \times 60 \times 60 \mathrm{~mm}$ dimensions.

The Ytong material was tested in accordance with norm PN-EN 1926: 2007 [6], whereas foam material by using the recommendations of ISRM (International Society for Rock Mechanics) [7].

While testing the Foam material, brittle failure of the whole sample did not occur but a thin layer of material adherent to the stand was destroyed, thus the tests continued until loosening of longitudinal pieces of the side surface of sample cylinder (from upper to bottom base occurred) (Tab. 6).

The results of the tests are presented in Table 6 and illustrated in Figures 6. 
TABLE 6

The results of compressive strength tests

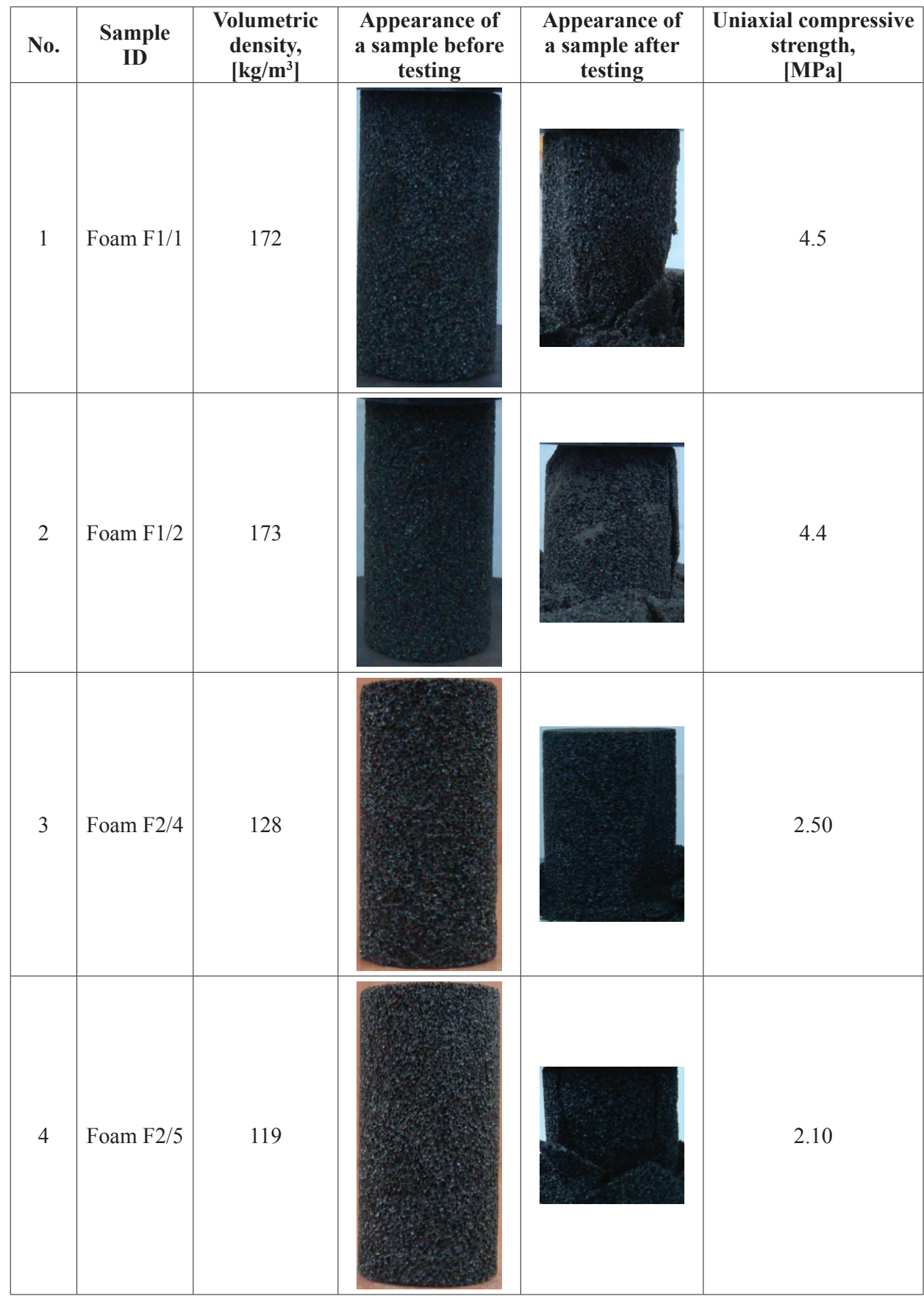


TABLE 6 cont.

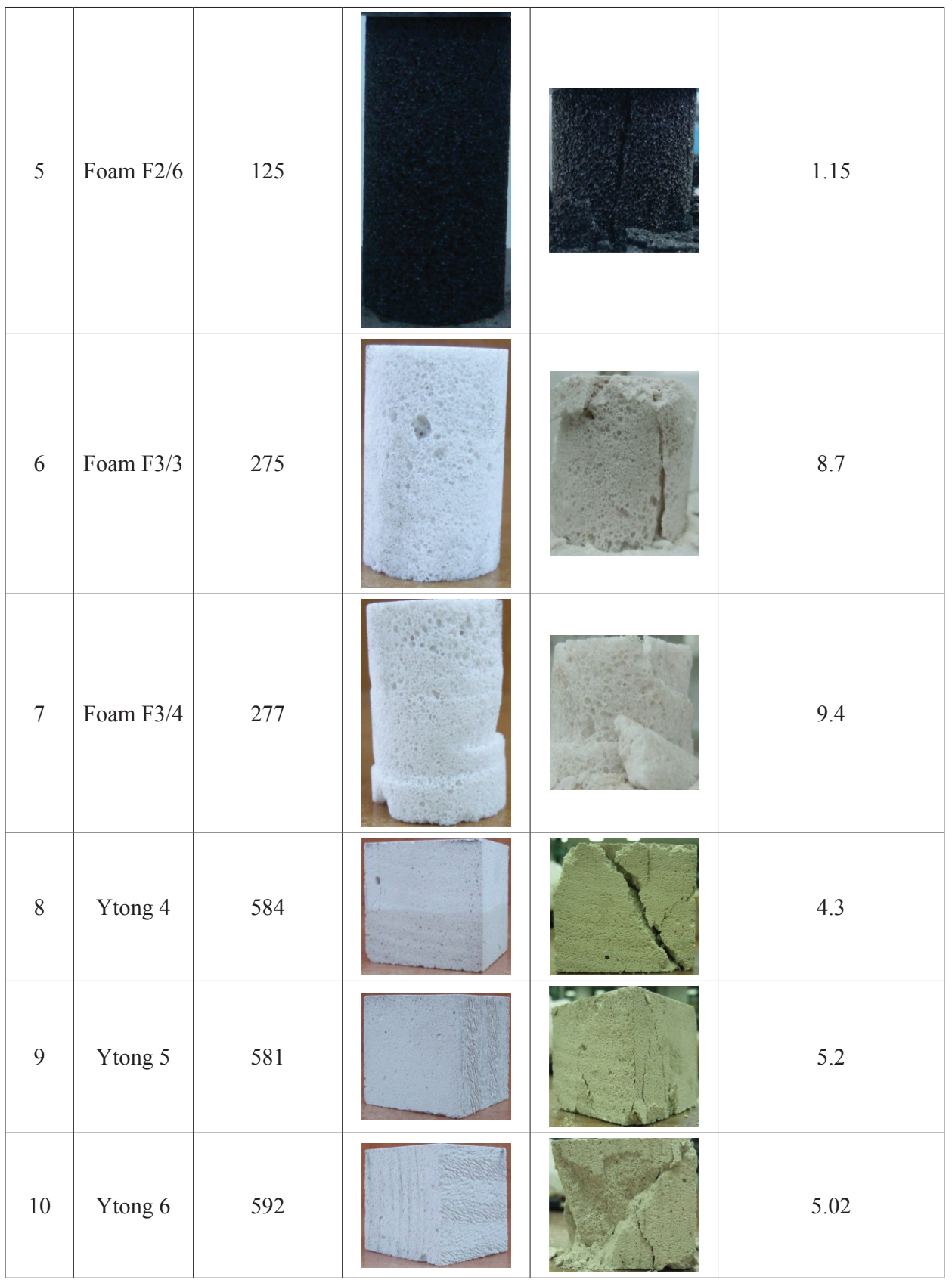

During the compressive strength testing of Foam material, a non-anomal increase in rock volume was recorded as well as brittle failure. The material underwent crushing from 
the base, at the side of applied force. The obtained stress-strain characteristics of foam material are similar to the characteristics complying with shearing of cohesionless formations (Fig. 6).

The tested cube samples of cellular concrete underwent brittle failure. Their compressive strength approximately amounted from 4 to $5 \mathrm{MPa}$. According to norm PN-EN 771-4: 2004/A1 [8], such strength corresponds to concrete 600 form.

a)

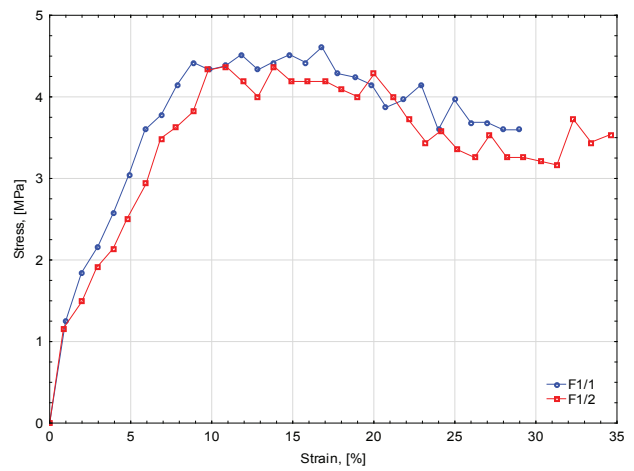

b)

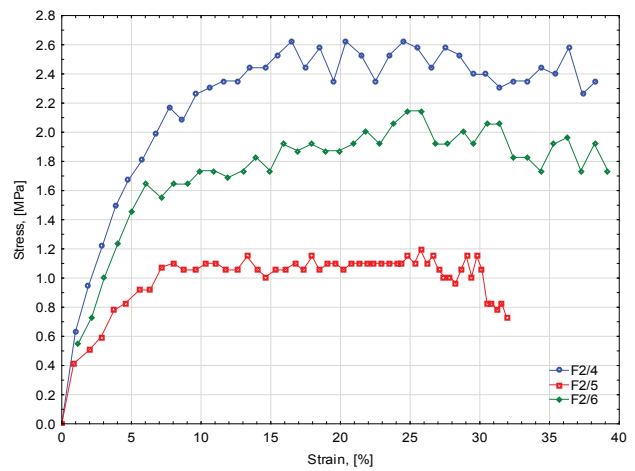

c)

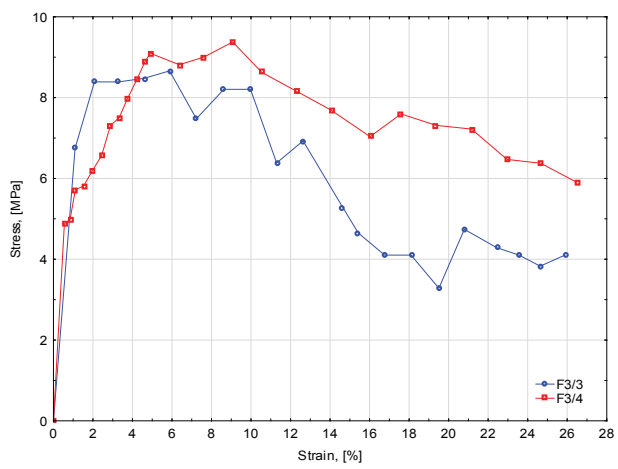

Fig. 6. Diagrams of compressive strength depending on strains: a) sample F1;

b) sample F2; c) sample F3

\section{Summary}

The solid material Foam tested is a hydrophobic material, which is characterized by very high porosity values (approximately 90\%), and very low values of volumetric density $\left(122-257 \mathrm{~kg} / \mathrm{m}^{3}\right)$. The material also showed relatively high values of cohesion and internal friction angle $\left(122.08-988.4 \mathrm{kPa}, 16.4-17.94^{\circ}\right)$. This material undergoes failure by laminar crushing at the point of the applied force. 
Material Ytong similarly to foam material has high porosity $(\sim 75 \%)$ and low volumetric density $\left(586 \mathrm{~kg} / \mathrm{m}^{3}\right)$. It is characterized by high cohesion amounting to $805 \mathrm{kPa}$, low internal friction angle $\left(5.23^{\circ}\right)$, and compressive strength included in the range from 4.3 to 5.2 MPa.

The tested loose (granular) materials were characterized by physical and mechanical properties close to physical-mechanical properties of fine sands, silt sands and humus sands.

\section{REFERENCES}

[1] PN-EN 1097 - 3, Badania mechanicznych i fizycznych właściwości kruszyw. Część 3: Oznaczenie gęstości nasypowej i jamistości, 2000

[2] PN-EN 1936, Metody badań kamienia naturalnego. Oznaczenie gęstości i gęstości objętościowej oraz całkowitej i otwartej porowatości, 2010

[3] PN-88/B-04481, Grunty budowlane. Badania próbek gruntu, 1988

[4] Das B.M.: Advanced Soil Mechanics, Second Edition, Taylor \& Francis, Philadelphia 1997

[5] Wilun Z:: Zarys geotechniki. Warszawa, Wydawnictwa Komunikacji i Łączności 2000

[6] PN-EN 1926, Metody badań kamienia naturalnego. Oznaczenie jednoosiowej wytrzymałości na ściskanie, 2007

[7] Ulusay R., Hudson J.A. (Ed.): The complete ISRM suggested methods for rock characterizations, testing and monitoring: 1974-2006. Ankara, 2007, Turkey

[8] PN-EN 771-4: 2004/A1, Wymagania dotyczące elementów murowych. Część 4: Elementy murowe z autoklawizowanego betonu komórkowego, 2005 